\title{
The epigraphic stela of Montoro (Córdoba): the earliest monumental script in Iberia?
}

\author{
Leonardo García Sanjuán ${ }^{1, *}$, Marta Díaz-Guardamino², \\ David W. Wheatley' ${ }^{2}$, Juan-Pablo Vita Barra ${ }^{3}$, José Antonio Lozano \\ Rodríguez ${ }^{4}$, Miguel Ángel Rogerio-Candelera ${ }^{5}$, Ángel Justo Erbez ${ }^{6}$, \\ Dominic Barker ${ }^{2}$, Kris Strutt ${ }^{2} \&$ Manuel Casado Ariza ${ }^{1}$
}

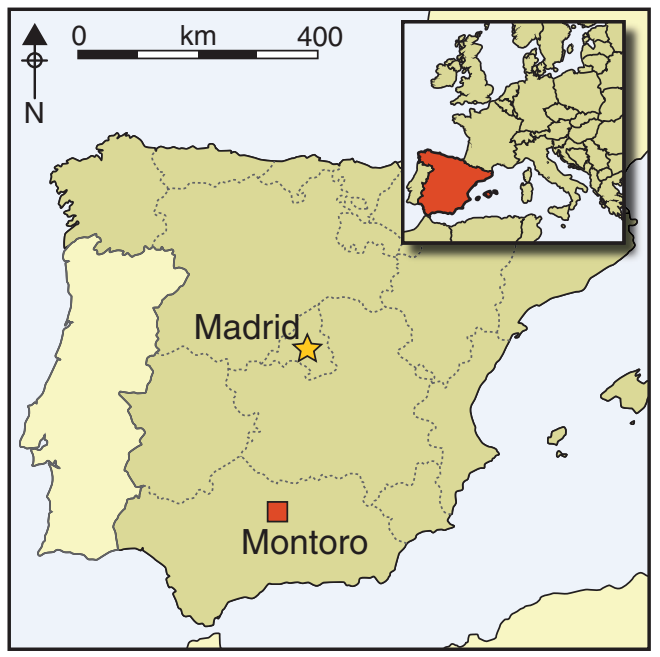

A remarkable stela from Montoro, southern Spain, is unique in its morphology, epigraphic traits and landscape context. A programme of chemical characterisation, digital imaging, and geo-lithological and epigraphic analyses were conducted to determine its age and significance, and the results were integrated with data from archaeological investigations of the surrounding area. This multi-faceted approach allowed the stela to be interpreted within the context of early interactions between literate Mediterranean societies of the Late Bronze Age and Iron Age and non-literate Iberian societies. A key outcome of this research is a wider understanding of the complex patterns in the use and perception of early scripts.

Keywords: Spain, Montoro, Torre de Villaverde, Late Bronze Age, Iron Age, stela, epigraphy

1 Departamento de Prehistoria y Arqueología, Universidad de Sevilla, Calle Doña María de Padilla s/n, 41004 Seville, Spain

2 Department of Archaeology, Southampton University, University Road, Southampton SO17 1BJ, UK

3 Instituto de Lenguas y Culturas del Mediterráneo y Oriente Próximo, Consejo Superior de Investigaciones Cientificas (CSIC), Calle Albasanz 26-28, 28037 Madrid, Spain

4 Instituto Andaluz de Ciencias de la Tierra, CSIC-Universidad de Granada, Avenida de las Palmeras 4, 18100 Armilla, Granada, Spain

5 Instituto de Recursos Naturales y Agrobiología, Consejo Superior de Investigaciones Cientificas (CSIC), Avenida Reina Mercedes 10, 41012 Seville, Spain

6 Instituto de Ciencia de Materiales, CSIC-Universidad de Sevilla, Calle Américo Vespucio 49, 41092 Seville, Spain

* Author for correspondence (Email: lgarcia@us.es)

(C) Antiquity Publications Ltd, 2017

ANTIQUITY 91358 (2017): 916-932 
He had seen everything, had experienced all emotions, from exaltation to despair, had been granted a vision into the great mystery, the secret places, the primeval days before the Flood. He had journeyed to the edge of the world and made his way back, exhausted but whole. He carved all his toils on a stone stela (Gilgamesh I: 7-10; Mitchell 2004).

\section{Introduction}

An exceptional epigraphic stela is currently kept at the Municipal Archaeological Museum of Montoro (Córdoba, Andalusia, Spain). This stela was accidentally unearthed in 2002 by ploughing in a plot adjacent to Torre de Villaverde, a Late Medieval site located approximately $3 \mathrm{~km}$ to the south of Montoro (Figure 1). Upon discovery, the stone was dragged to a clearance cairn on the edge of the field, where it was found in 2004, lying face down, by rangers from the Ministry of Environment of the Andalusian Regional Government (Figure 2). A series of archaeologically significant engraved motifs were immediately observed on the stone, and a decision was made to transport it to the Montoro Museum.

In April 2012, we visited the Museum to conduct a preliminary inspection of the stone and confirmed that it was in fact a stela with numerous engraved motifs. The universities of Seville (Spain) and Southampton (UK) initiated a two-year project to study this remarkable, yet unstudied, stela with its unique motifs. Research focused on characterising the stela itself using geo-lithological analysis, digital recording, surface texture analysis and epigraphic interpretation of the motifs. A field study of the find location was also performed. This included intensive surface and geophysical surveys, and test pit excavations.

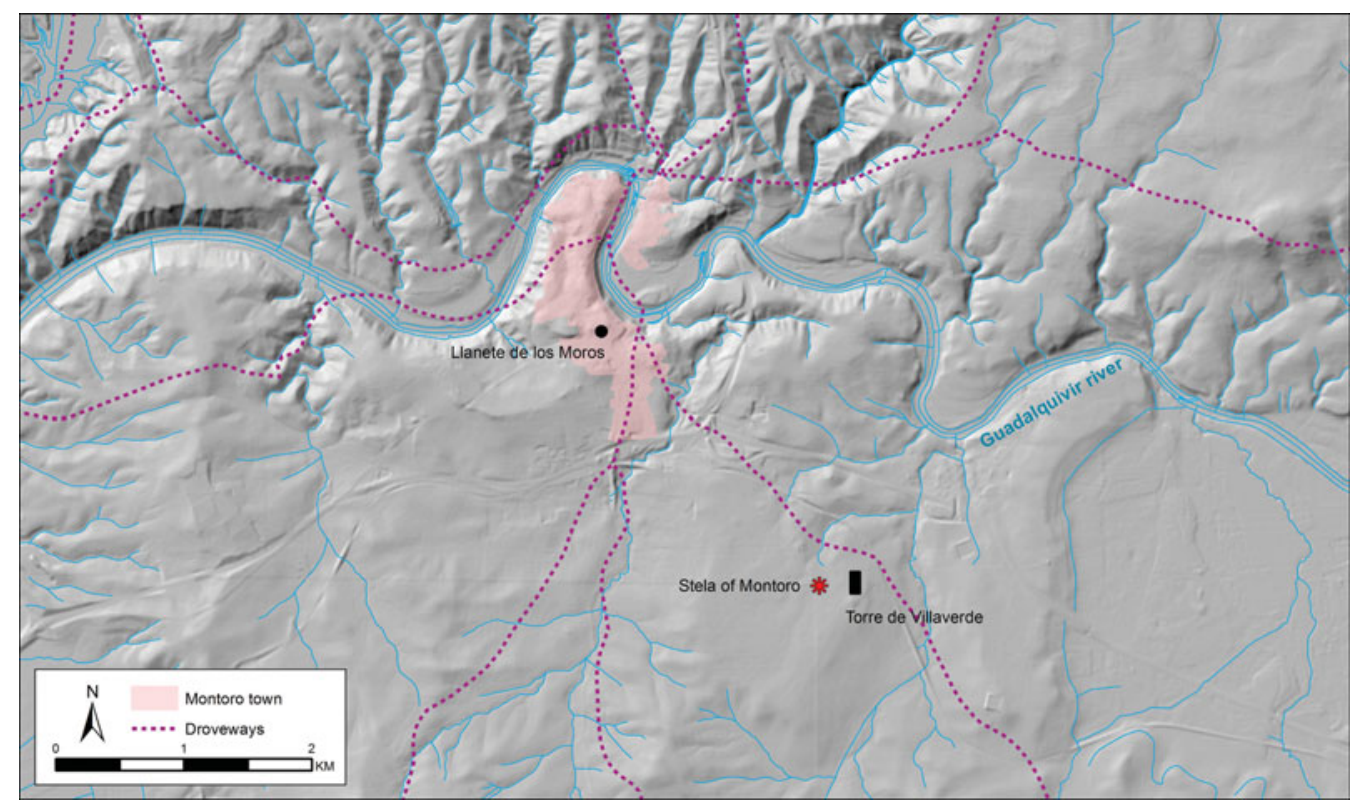

Figure 1. Location of the stela within the Montoro municipality. Design: Marta Diaz-Guardamino.

(C) Antiquity Publications Ltd, 2017 


\section{Description}

\section{Morphology, geological characterisation and graphic reproduction}

The Montoro stela has a height of $1.5 \mathrm{~m}$, a maximum width of $0.85 \mathrm{~m}$ and a maximum thickness of $0.31 \mathrm{~m}$. It is, in general, similar in size to the Late Bronze Age/Early Iron Age 'warrior stelae', which are

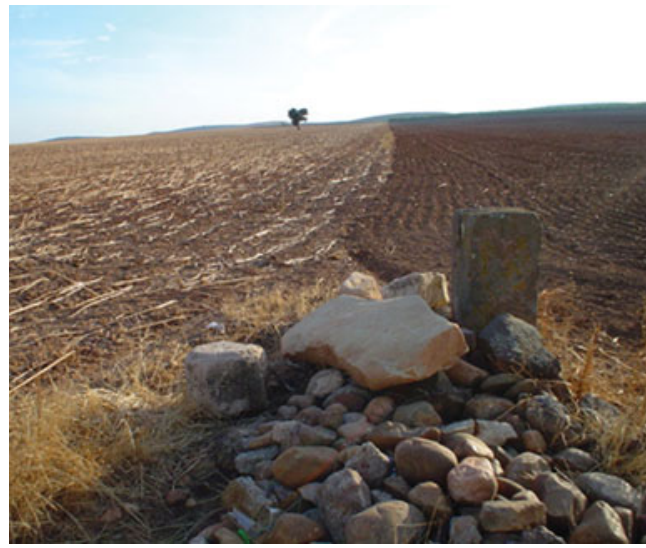

Figure 2. Original position of the stela as discovered in the clearance cairn. Photograph: José Romero Pérez. sometimes referred to as 'South-Western stelae' (Díaz-Guardamino 2010: 327-40) (Figure 3). With the exception of various scratches on its right side, its state of preservation is quite good: the original stone seems to be completely preserved, with a noticeable absence of lichens and wear. This suggests that the stone may have been protected in a roofed building, had a short use-life prior to deposition, or both. Geophysical evidence for a possible building or enclosure associated with the find location is discussed below. Display placement of the stela in the Museum prohibited study of the reverse side.

Geological characterisation of the stela is based on a petrographic thin section made from a sample taken from an accessible spot on its reverse side (Figure 4). This study reveals that the stone is a subarkose of detrital sedimentary origin, with a predominant proportion of quartz and feldspars, with some exotic grains such as micas, apatites, metallic ores and phyllosilicates. The grain is of fine sand size with a matrix-supported texture, in some cases supported with shapes ranging from subrounded to angular, which are barely classified. Of particular note is the presence of a source of very fine-grained sparite cement and the great abundance of microfossils - mainly planktonic foraminifera of the Globigerina typemiliolids (with a porcellanous shell), and the presence of calcareous algae (Halimedas), thinshelled Lamellibranchia and echinoderm spines. Rocks of detrital sedimentary origin, more specifically from the coastal facies characteristic of the Upper Miocene, appear in the area surrounding Montoro. This suggests that the stela was made locally. The hardness and resistance of the rock undoubtedly influenced the good state of preservation and must have proved a challenge to the creators of the motifs.

The obverse side presents several areas with reddish/orange pigmentation. This raised the question of whether the pigments were intentionally applied in association with the motifs, or whether they were naturally derived. To resolve this, a photomosaic of the obverse was made from digitally rectified photographs to conduct digital image analysis. Four samples (EM-1 to 4) were also taken for characterisation using X-ray diffraction (XRD) and scanning electron microscopy with energy dispersive X-ray spectroscopy (SEM-EDX). Digital image analysis (see Rogerio-Candelera et al. $(2010,2011)$ for a complete description of the method used) suggests no intentional application of the reddish/orange colour (Figure 5). SEM-EDX analysis detected essentially the same elements (C) Antiquity Publications Ltd, 2017 
in the four samples, with silicon predominating in all of them (two of the samples included magnesium), and a very low quantity of iron. Thus, the colour can be interpreted as impurities in the rock mineral,

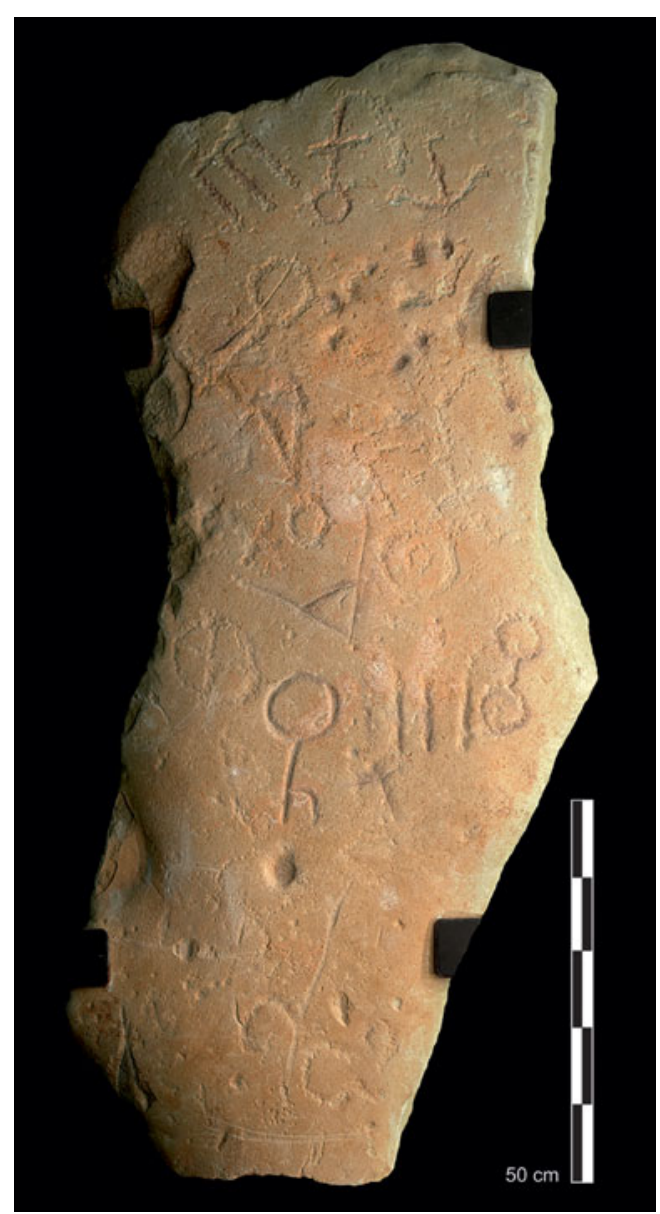

Figure 3. The stela as it is currently displayed in the Montoro Museum. Photograph: Marta Diaz-Guardamino. rather than intentionally applied pigment (see Figure $\mathrm{S} 1$ in online supplementary material). XRD analysis of samples EM-1 to 4 detected calcite $\left(\mathrm{CO}_{3} \mathrm{Ca}\right)$ and quartz $\left(\mathrm{SiO}_{2}\right)$ in all four. EM-1 and 2 contained anorthite $\left(\mathrm{CaAl}_{2} \mathrm{Si}_{2} \mathrm{O}_{8}\right)$, while sample EM-3 contained microline $\left(\mathrm{KAlSi}_{3} \mathrm{O}_{8}\right)$. Anorthite is a variety of plagioclase that is primarily found in limestone that has undergone contact metamorphism. Microcline is a mineral from the feldspar group that appears in high grade metamorphic veins, hydrothermal veins, as a detrital component in sedimentary rocks, and as an authigenic mineral. Results from digital image processing, SEM-EDX and XRD do not, therefore, suggest the presence of intentionally added pigments. The observed reddish/orange stains are either part of the mineralogical composition of the base rock, or the result of migration of amorphous iron oxides due to taphonomic processes.

Having discounted the possibility that the stela had been painted, we focused on recording and analysing the engraved motifs. For this, we employed Reflectance Transformation Imaging (RTI), which uses transformation of the reflectance properties of any surface to enhance the perception of its texture and shape (see

Díaz-Guardamino \& Wheatley (2013) for a full description of the method). RTI is an inexpensive, non-contact and robust method for the documentation and interactive visualisation of artefacts, and is particularly powerful for rendering engravings. Two RTI captures were performed on the obverse of the stela, with an average of 95 photographs each, at maximum resolution (21.1 megapixels) and in CR2 and JPG formats. The RTI allowed us to document, analyse and interpret the subtlest details on the engraved surface. This resulted in a synthetic line drawing that sums up our graphic interpretation of the monument (Figures $6 \& 7$ ), which included discernment of the engraving techniques employed, and delineation of the engraved motifs (essential for their epigraphic analysis). 

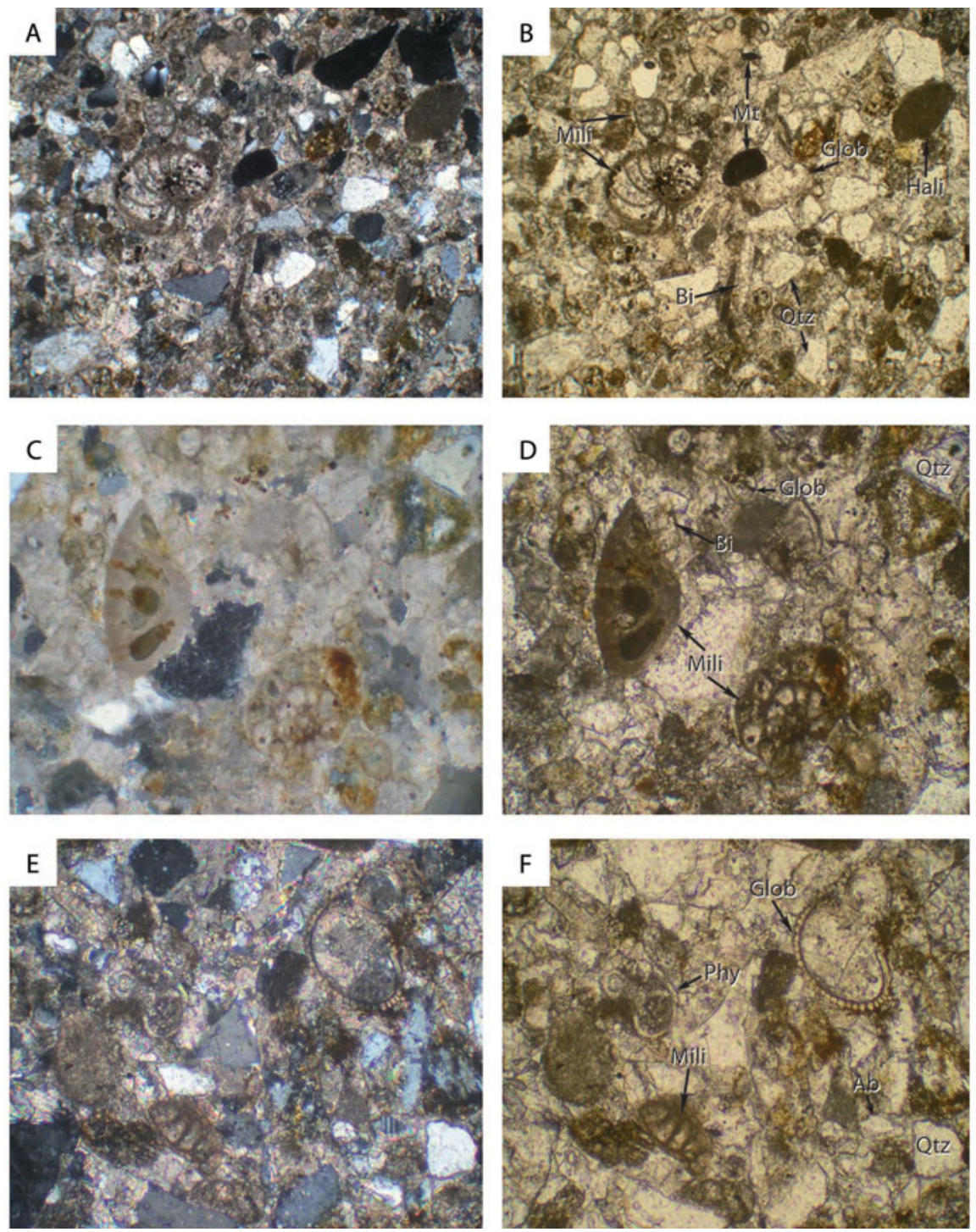

Figure 4. Thin-section micro-photographs of the sample taken from the stela. Images $A, C$ and $E$ are taken with crossed nicols; images $B, D$ and $F$ show the same area of the thin section without crossed nicols. Images are $4 \times$ in micro-photographs $A$ and $B$, and $10 \times$ for all others. Mill: miliolids; Mt: metallic ore; Glob: Globigerina; Hali: Halimeda; Bi: bivalve; Qtz: quartz; Phy: phyllosilicates; Ab: albite. Design: José Antonio Lozano Rodriguez.

When considering the engraving techniques, it must be emphasised that the naturally smooth and regular appearance of the obverse surface suggests that it was not prepared prior to engraving. Various techniques were used to engrave the motifs or signs:

1) Wide, dense and deep pecking: used in 15 motifs/signs, including 10 graphemes (\#1-4, 7-9, 11, 13 and 16) and two doubtful graphemes (\#6 and 10).

(C) Antiquity Publications Ltd, 2017 


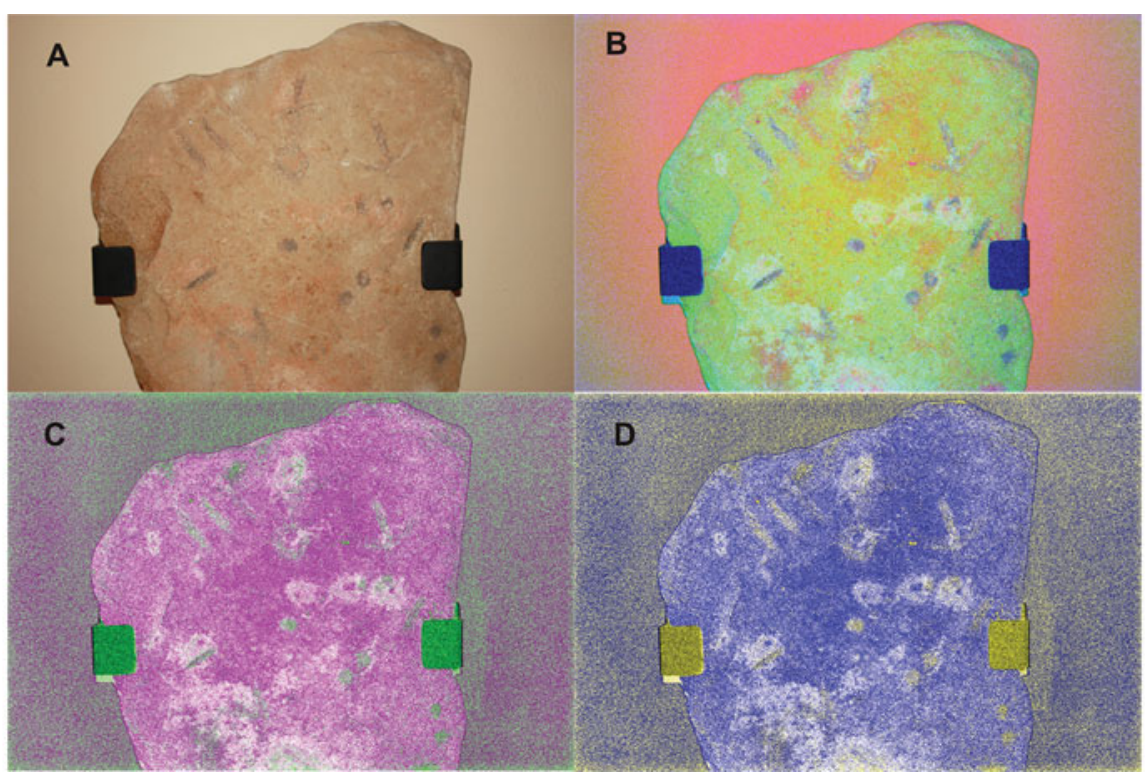

Figure 5. A) RGB 1628 image, base for the following; B) false colour image using the three PCA bands (PC123); C) false colour image pondering the second Principal Component (PC232); D) false colour image pondering the third Principal Component (PC 332). Design: Miguel Angel Rogerio-Candelera.

2) Incision/pecking and abrading: used in three motifs-signs, two of which are graphemes (\#14 and 15).

3) Incision and abrading: used in three motifs-signs, one of which is a certain grapheme (\#12), another a doubtful one (\#17).

4) Shallow and/or dispersed pecking: used in eight motifs-signs of uncertain interpretation, one of which is a concentration of pecking.

5) Cup marks: on the front side of the stela there are different individual or clustered cup marks (\#18, 22, 26 and three possible groups of small cup marks that have not been numbered).

6) Possible unfinished motifs (\#23, 24 and 31).

7) Plough marks/damage.

In total, 31 engraved elements (individual motifs-signs or groups of motifs-signs-cup marks) were identified, delineated and characterised, in addition to three possible groups of 'cup marks' that were not numbered. The use of RTI was essential to: i) identify shallow motifs that are difficult to see with the naked eye; ii) identify superposition of a series of small cup marks; and iii) outline the tentative sequencing of the motifs (Figure 7).

\section{Epigraphy}

Of the 31 engraved motifs, a large number $(\# 1-11,19)$ are located around cup mark \#18, with signs \#12 and \#20 (perhaps engraved at an earlier stage) providing the lower boundary. 


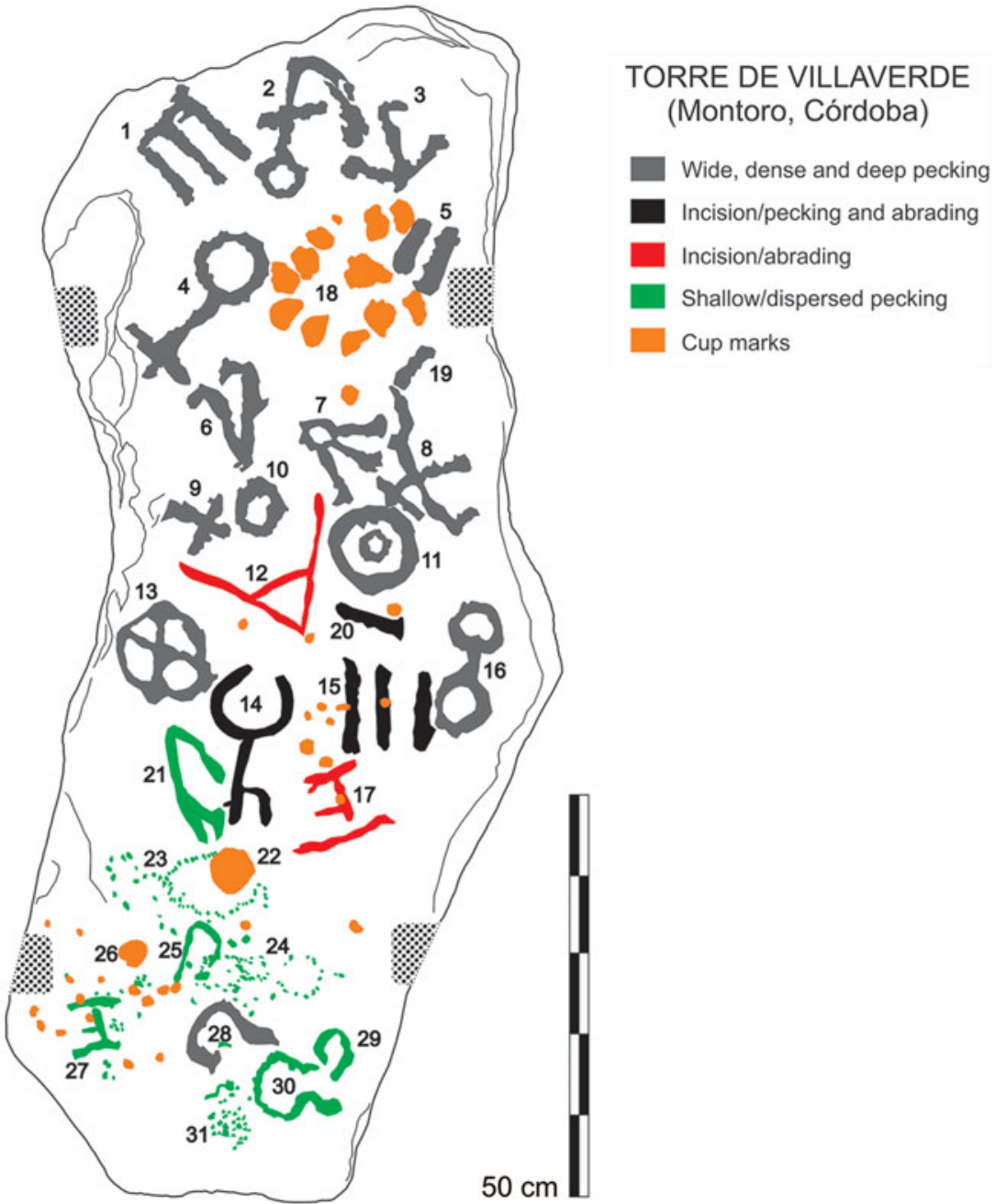

Figure 6. Synthetic vector line drawing of the stela's obverse with the numbers given to all motifs-signs. Design: Marta Díaz-Guardamino.

Signs \#13 and \#16, probably engraved at the same time as signs \#1-11 and \#19, form an imaginary line, above which signs \#1-11 and \#19 appear in a circular arrangement, somewhat reminiscent of the circular or spiral orientation of writing on some Early Iron Age stelae with 'SW Palaeohispanic' script (cf. De Hoz 2010: 357).

Epigraphic analysis of the Montoro stela reveals that many of the engraved motifs are compatible with several Iberian Iron Age scripts. This is consistent with the geographic location of Montoro, which lies near the south-eastern edge of the 'SW Palaeohispanic'(or 'Tartessian') stelae script distribution, and near the western edge of the 'SE Palaeohispanic' (or 'Meridional') script range. Additionally, some of the Montoro stela motifs are similar in form to those found in eastern Mediterranean scripts dated to the late second and entire (C) Antiquity Publications Ltd, 2017 
first millennium BC (such as Proto-Canaanite, Proto-Sinaitic and South Arabian). The lack of a precise chronology for the Montoro stela requires a broad interpretative approach.

Of signs \#1 to 21 , at least 13 are liable to interpretation as graphemes. Some signs could be variants of others. Signs \#21 to 31 are excluded from this interpretation, with the exception of sign \#27 (very similar to motif \#17).

Signs \#1 and 15: sign \#1, 7 , is present in the NE Palaeohispanic script with the syllabic value to (De Hoz 2010: 618, 2011: 739, 742, 744), as well as in Graeco-Iberian script with the value $\mathbf{s}$ (De Hoz 2011: 737). It is possible that sign \#15, 19, is a variant of \#, although the horizontal line that should join together the three vertical lines (numbered 20) is loose, and appears to be incised between signs \#15 and 11. More questionable, although it should still be considered, is that sign \#5 is a variant of sign \#15.

Signs \#2, 4 and 8: sign \#2, $\mathcal{F}$, seems to have two parts, including a pecked main body and then a pecked, intentional prolongation at the base. The prolongation exhibits a more disordered, shallow and careless pecking than the main body, which perhaps suggests that this part was engraved by a less proficient hand. It is, however, impossible to discern whether they were both produced at the same time. The Montoro stela presents, in our opinion, two more variants of this sign. The first is sign $\# 4,7$, and the second is sign 4 . Only distant oriental parallels can be found for both of these signs; for instance, the sign with the value of $\mathbf{h}$ from Proto-Sinaitic and Proto-Canaanite inscriptions (see Sass 1988: 183-84).

Sign \#3, To, finds possible parallels in the sign $\mathbf{p}(\mathbf{i})$ from SW Palaeohispanic script (De Hoz 2010: 618, 620), in the sign bí of SE Palaeohispanic (De Hoz 2010: 618, 620, 2011: 741), and in the sign u from NE Palaeohispanic (De Hoz 2010: 618, 2011: 739, 742, 744). It should be noted that SW and SE Palaeohispanic scripts are closely similar in the forms and phonetic values of their signs-i.e. they are variants of one system.

Sign \#7, $F$, could find graphemic parallel in the variant be7 of the NE Palaeohispanic sign be (De Hoz 2011: 743). Although more distant, there is a possible similarity with the sign ș from epigraphic South Arabian (O’Connor 1996: 101; Stein 2013: 211).

Sign \#9, $\%$, has a multitude of parallels both in Iberian and Near Eastern scripts. Limiting ourselves to Iberia, we can highlight a parallel to the sign $\mathbf{t}$ from Phoenician, $\mathbf{t}(\mathbf{a})$ from SE Palaeohispanic (De Hoz 2010: 620, 623) and to ta from NE script (De Hoz 2010: 618), among others.

Sign \#11, (), has a possible parallel in the sign ku from NE Palaeohispanic (De Hoz 2010: 618, 2011: 739, 742, 743).

Sign \#12, $\triangleleft$, could reflect both the Phoenician consonant' and a variant of the grapheme a from SW Palaeohispanic (De Hoz 2010: 620, 623, 625), SE scripts (De Hoz 2010: 618, 625, 2011: 741), or from Graeco-Iberian (De Hoz 2011: 737).

Sign \#13, $\theta$, finds its best parallels in Iberia in the Phoenician sign $\mathbf{t}$, in the variant $\mathbf{e} 4$ from SE Palaeohispanic (De Hoz 2011: 741), and in the variants te12 and te13 from the NE sign te (De Hoz 2011: 744).

Sign \#14: the circle of the sign $h$, made with incision/scratching and abrading, does not close in its upper part (as proven conclusively by RTI). Nonetheless, the shape is 
Table 1. Signs showing possible variants.

\begin{tabular}{lcc}
\hline Signs & & \\
\hline$\# 1$ and 15 & in & $191+\# 20$ \\
$\# 2,4$ and 8 & $f$ & 9 \\
\hline
\end{tabular}

strikingly reminiscent of the grapheme employed in epigraphic South Arabian to represent the phoneme $\mathbf{z}$ (O'Connor 1996: 101; Stein 2013: 211).

Sign \#16: the sign \& has a similar morphology to that of SW script, with a possible $\mathbf{k}(\mathbf{i})$ value (De Hoz 2010: 621). It also has the same morphology as the grapheme employed in epigraphic South Arabian to represent the phoneme to'Connor 1996: 101; Stein 2013: 211).

Other signs are more questionable in terms of whether they could be graphemes. Signs $\# 6, \mathbb{A}$, and $\# 10,0$, could be independent signs. If so, the $\theta$ could be interpreted as a grapheme. We believe, however, that they are more likely to be components of the same sign

A. As with signs \#2, 4 and 8, this sign could represent some type of human figure. Suitable parallels for this sign in late second-and first-millennium BC Iberian and Near Eastern scripts are difficult to find using either grapheme reproduction or forced comparison (for example, with the sign be from NE Palaeohispanic—see De Hoz 2011: 742). Sign \#17, ヨ, does not resemble a grapheme, although it may have a clear parallel in sign \#27, 1 . Each sign has been engraved using a different technique (\#17: incision/abrading; \#27: pecking). For signs \#11 and \#13, it should be noted that their forms occur as chariot wheels in some Late Bronze Age/Early Iron Age 'warrior' stelae.

As has been seen, it is possible that 2 of the 13 signs present in the stela display variants, as shown in Table 1 . If this interpretation is correct, 10 signs could be interpreted as graphemes. Signs \#10 and \#17 (analogous to \#27) could expand this list.

\section{Landscape context and fieldwork}

The stela was located in the southern part of the Montoro municipality, adjacent to the Torre de Villaverde and a droveway, on a slight elevation that slopes gently towards the Guadalquivir River (Figure 1). Pre-Roman coins and painted pottery have been found in the surrounding area. Carthaginian coins and Roman pottery and construction material have also been recovered. Some of these finds are kept at the Montoro Museum. The Torre de Villaverde is a medieval watchtower reconstructed in 1472 by Diego de Aguayo, in the Late Gothic style.

A semi-intensive survey was initially carried out in the area where the stela was discovered (Figure 8). A field survey of a $4500 \mathrm{~m}^{2}$ area was undertaken by a team of five people, spaced $7 \mathrm{~m}$ apart. The survey recorded a small, varied assemblage of medieval and modern materials, with no patterns or concentrations characteristic of protohistoric archaeology emerging. Consequently, an alternative strategy of intensive random sampling was adopted to characterise the archaeology of the area immediately surrounding the stela location. Six 


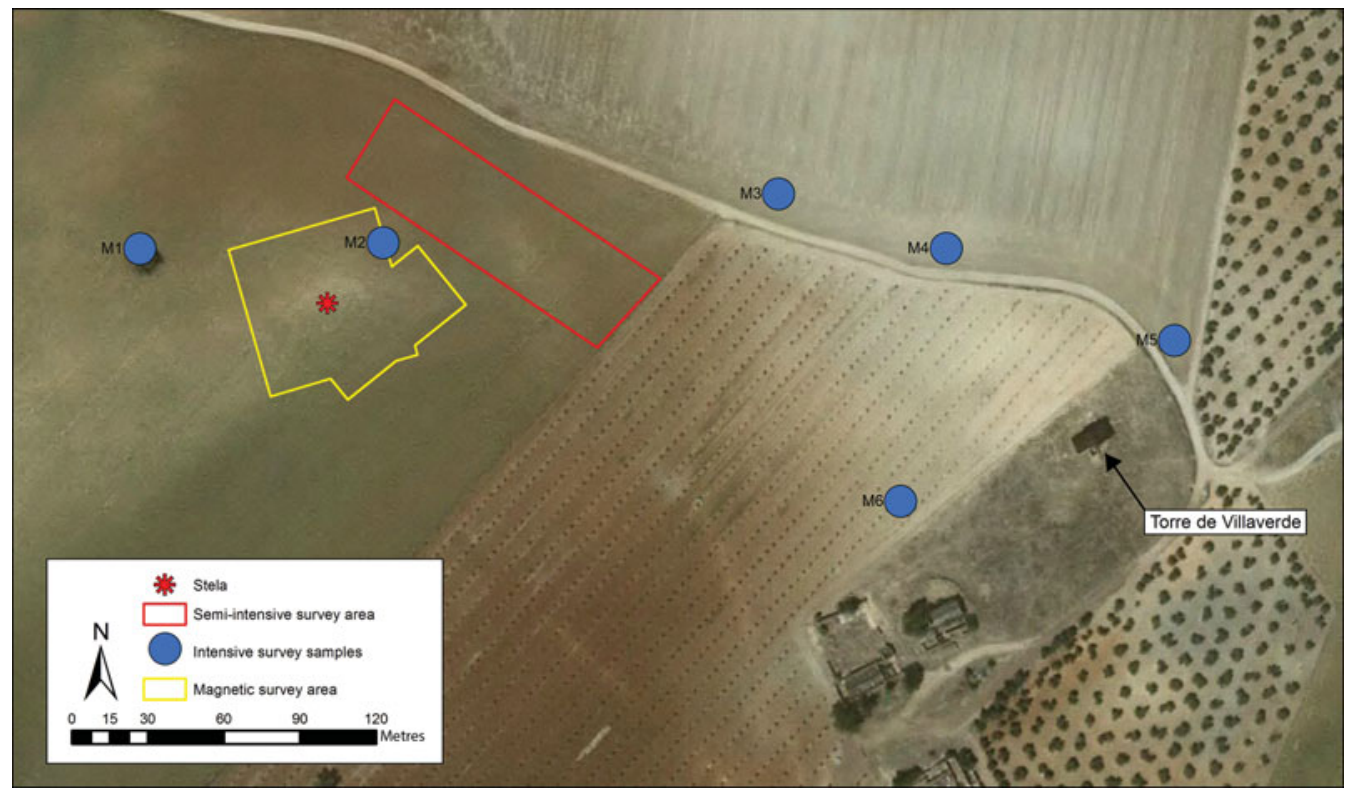

Figure 8. Plan showing the survey areas. Design: Marta Diaz-Guardamino.

random points (designated M1-M6) were selected. In each one, a circular area with a $1 \mathrm{~m}$ radius was surveyed (six circular areas measuring $3.14 \mathrm{~m}^{2}$ each for a total of $18.84 \mathrm{~m}^{2}$ ) (Figure 8). All of the archaeological material recorded in these areas was weighed and assessed in terms of typology, but was not retained. The assemblage consisted almost entirely of modern and medieval pottery and construction materials. Its concentration (measured by weight, not by number of items) varied by area, increasing as the distance from the Torre de Villaverde decreased.

The magnetic survey was conducted using a Bartington Instruments Grad 601 dualsensor fluxgate gradiometer, covering four grids measuring $30 \mathrm{~m}$ on each side (thus covering a total area of $3600 \mathrm{~m}^{2}$ ) over the spot where the stela was found. Upon completion of data analysis, it was realised that part of the disused Málaga-Puertollano oil pipeline ran through the site, producing significant magnetic interference. Despite this, various linear anomalies surrounding the stela findspot were detected, including features that may represent a rectilinear building or enclosure (Figure 9).

To investigate this, a test pit measuring $2.5 \times 1.5 \mathrm{~m}$ was excavated in the north-eastern corner of the putative building/enclosure (Figures $9 \& 10$ ). This excavation was conducted to an approximate depth of $0.4 \mathrm{~m}$ before reaching the bedrock. No walls, wall foundations or any other type of architectural remains (floors or construction material) were encountered. Two small, very shallow ditches were identified (between 0.3 and $0.5 \mathrm{~m}$ deep). One of these was located on the southern side of the test pit, with an approximate west-east orientation, and the other in the north-east corner of the pit, with a north-east-south-west orientation (Figure 9). Cultural material from these ditches was sparse and non-diagnostic, making interpretations of the date and function of these features very difficult. Seventynine pottery fragments were collected, of which 70 are wheel-thrown and 9 hand-thrown,

(C) Antiquity Publications Ltd, 2017 


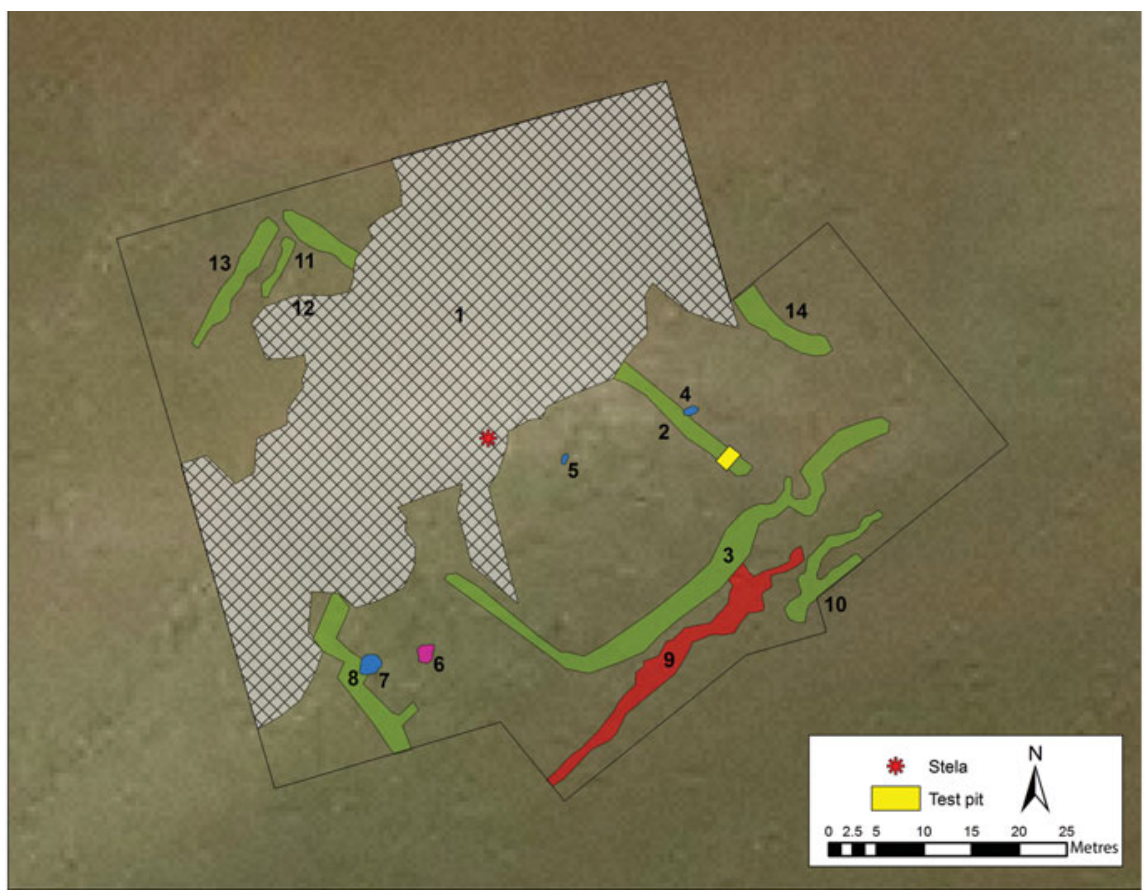

Figure 9. Interpretation of the magnetic survey. Each anomaly is numbered separately. Anomaly number 1 is the disturbance caused by the oil pipeline. Design: Kris Strutt, Dave Wheatley and Marta Diaz-Guardamino.

which are characteristic of surface deposits at settlement sites along the Guadalquivir Valley. Typologically, they include a mixture of very diverse types and dates. Only seven wheelthrown items have a recognisable shape, in addition to a possible ceramic lamp fragment, and a few possible fragments of imbrices (roof tiles). With the exception of the small rim of glazed pottery, the rest of the shapes can be generally dated to the early Roman Empire

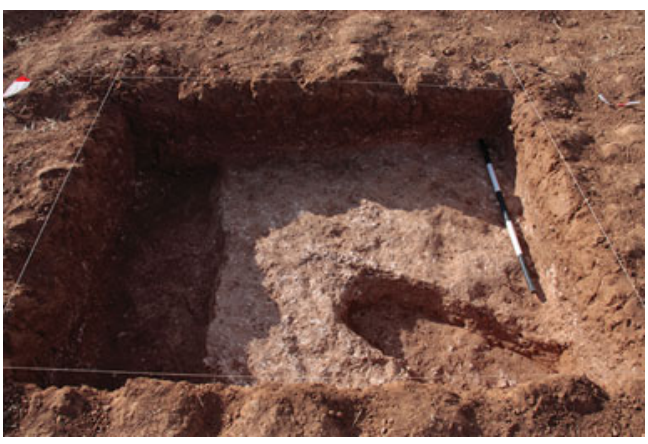

Figure 10. Test pit at the stela location. Photograph: Leonardo García Sanjuán. (first to third centuries AD). The handthrown pottery is limited to nine possible fragments of non-diagnostic shape.

Unfortunately, by decision of the landowner, it was not possible to expand the test pit or to open further pits. With the available geophysical data, it is, therefore, only possible to suggest the presence of a large rectilinear building or enclosure of unknown date in close proximity to the stela findspot. Although pottery collected from the surface and the test pit is representative of local occupation during antiquity and the Middle Ages, no clear Iron Age evidence was found.

(C) Antiquity Publications Ltd, 2017 


\section{Discussion}

The first question raised by our study is: can the Montoro stela be interpreted as an inscription? If so, is it possible to read and understand it? Before attempting to answer these questions, the following circumstances must be noted. Firstly, if it is an inscription, no element can be identified that establishes the beginning and end points of the writing. Secondly, the signs do not present sufficient consistency to represent a single, specific writing system: no known writing system to date can, on its own, provide coherence to all of the signs. Thirdly, there is a lack of archaeological information regarding the original position of the stela (e.g. how it was placed in the ground), which can affect the morphological analysis of the signs. The stone could have been sitting vertically (e.g. as in Figures 3, $6 \& 7$ ), as the majority of the more elaborate engraved motifs are concentrated on the upper two-thirds of its surface, while the lower section displays less elaborate or seemingly unfinished motifs. We cannot, however, discount the possibility that the stone was placed horizontally, as there are no apparent differences in the texture or colour of the surface of the obverse side; some Iberian Bronze Age and Early Iron Age stelae were found buried, a few of which were found covering tombs, with the decoration facing down (although the position of some of these could have been due to reuse-see DíazGuardamino 2010: 312-19, 368-73).

Two further issues require attention: a) it is usually impossible to decipher a script without any indication of how its signs are meant to be read (additionally, in this case, there is no information of what type of language might be represented); and b) the above problem becomes further complicated if only one copy of that writing exists, as is the case with this stela.

Despite these problems, we tentatively suggest that the Montoro stela may present signs that either belong to, or wish to emulate, some type of protohistoric script. We consider the latter to be more likely. The majority of the signs have possible parallels in southern Iberian Iron Age writing systems: Phoenician, Graeco-Iberian, and SW, SE and NE Palaeohispanic scripts. As noted above, this is consistent with the geographic location of the stela. Nevertheless some graphemes find potential parallels in Levantine and Near Eastern scripts. Signs \#7, 14 and 16 have parallels in epigraphic South Arabian, as evidenced from the eleventh and tenth centuries BC onwards (Stein 2013: 32-33). The South Arabian alphabetical order is already demonstrated by cuneiform alphabets from Ugarit and BetShemesh from at least the thirteenth century BC and sign \#2 (= 4 and 8 ) in Proto-Sinaitic and Proto-Canaanite (these have highly debated dates, but always fall within the second millennium BC). In these latter cases, we do not claim a direct dependency of the stela's signs on Near Eastern inscriptions. This is a reminder, however, of the ultimately Near Eastern origin of all Iberian protohistoric scripts, and must be considered when assessing the Montoro stela.

Although its signs do not form a legible and comprehensible inscription, the Montoro stela could have only been produced in a social context in which writing existed. The engraver(s) must have been exposed to some type (or types) of writing. Those who engraved the signs probably did not know how to read and write them. Rather, they probably reproduced signs that they knew or perceived as graphemes. The hard work involved in

(C) Antiquity Publications Ltd, 2017 
engraving the stone to create what is indeed one of the largest protohistoric pre-Latin epigraphic monuments in Iberia indicates the importance of the signs (and graphemes). It is also important to note that, with the data presented here, we cannot rule out the possibility that the engraving was undertaken in more than one session over an indeterminable period of time. Stelae are monuments that, by their very nature, can be used or reused over long periods. On the Iberian Peninsula, cases are known of prehistoric stelae that were later reengraved with Tartessian and Latin inscriptions (see examples in García Sanjuán \& DíazGuardamino 2015: 189-96).

Our hypothesis is that the engravers of the Montoro stela wished to materialise the prestige of writing as a communication tool, without necessarily knowing how to use (or wanting to use) the signs as writing. This hypothesis is partly supported by the organisation of the signs: on what we interpret as the upper part of the stela, signs \#1 to 11 (graphemes) are arranged in a circle around sign \#18 (non-grapheme), which consists of 11 cup marks, 10 of which form a circle around the other one. These 11 graphemes that form a circle have signs \#12 and 20 (graphemes), possibly engraved at a different point in time, as their lower limit.

There are known cases in which signs from established writing systems were used by non-literate (or literate but foreign) individuals or communities who had access to them, but could not read or write them in a grammatically meaningful way. A well-known example is the silver Phoenician bowl discovered in the Bernardini tomb in Preneste (Italy). This displays an Egyptian-like iconography, with the addition of three inscriptions that are Egyptian-hieroglyphic in appearance. The inscriptions were analysed by the French Egyptologist Gaston Maspero, who concluded that:

The signs do not form a continued text. They are signs or even complete words that are taken at random and juxtaposed without any concern for the meaning [...] the cartouches only contain untranslatable signs whose joining does not produce any name (Maspero 1883: 216).

It is possible that the artisan, unfamiliar with Egyptian language and writing, used these signs solely for their symbolic or decorative value, or for their prestige.

Given the nature of the engraved graphemes and the archaeological features of the immediate landscape, the most plausible chronological-cultural context for the Montoro stela is the Iron Age. The hypothesis for a vaguely 'symbolic' rather than strictly 'grammatical' meaning gains credibility when framed in this chronological context; during the ninth century cal BC, local southern Iberian societies experienced increased exposure to eastern colonists and traders who used Phoenician scripts (and perhaps other scripts). Two hypotheses are possible depending on whether an Early Iron Age ( $c$. $850-550 \mathrm{cal} \mathrm{BC})$ or a Late Iron Age $(c .550-200 \mathrm{cal} \mathrm{BC})$ chronology for the stela is preferred.

\section{Hypothesis 1}

The strongest evidence for the first writing in Iberia is currently considered to come from the eighth-seventh-century BC levels of the Phoenician site of Doña Blanca (Cádiz) (Zamora López 2005: 174-75). Alternatively, the oldest graffiti in SW Palaeohispanic script 
can be dated to the early or middle eighth century BC (Correa Rodríguez \& Zamora López 2008: 189). This evidence does not, of course, prove that those two scripts (or others) were not known by earlier southern Iberian societies. A number of (perhaps contentious) arguments have been proposed in favour of a Late Bronze Age chronology for the SW Palaeohispanic script (Ruiz-Gálvez 2009: 110-11, 2013: 304-309). Perhaps it seems too much of a coincidence that just $3 \mathrm{~km}$ to the north of the Montoro stela location lies the Late Bronze Age and Iron Age settlement of Llanete de los Moros- the only site in Iberia where confirmed Mycenean pottery (dating to the fourteenth century BC) has been found (Martín de la Cruz 1988, 1990). This suggests the probable early contact of local, nonliterate populations with writing. The pecking technique usually employed to engrave Late Bronze Age 'warrior stelae' (e.g. Díaz-Guardamino \& Wheatley 2013) was still in use when the Montoro stela was made, but had fallen out of use when the Early Iron Age SW Palaeohispanic corpus was produced using the newer incision technique. Unfortunately, as was previously discussed, the fieldwork data presented here cannot provide a date for the stela.

\section{Hypothesis 2}

Alternatively, very substantial Late Iron Age remains, including Carthaginian and (indigenous) Iberian coins and pottery, have been found in proximity to the Torre de Villaverde. The period from the middle of the sixth century to the end of the third century BC saw intense contact between southern Iberian populations and those of Eastern and North African origin who used writing. The last third of the third century BC saw Carthaginian military expansion and the Second Punic War (218-201 BC). The resulting armies in the Guadalquivir Valley included mercenaries of mixed origin, many of whom were undoubtedly familiar with such scripts and signs as those found on the Montoro stela.

Beyond the hypotheses that may explain this exceptional monument in terms of epigraphy and chronology, the Montoro stela has highly significant landscape characteristics. The location is in a strategic position: adjacent to a droveway and very close to a ford on the Guadalquivir River. The immediate presence of a medieval watchtower (which formed part of a regional system of surveillance including other towers) reinforces the strategic character of this location. With reference to the landscape, the Montoro stela has strong concomitances with the 'warrior stelae' of south-western Iberia. In many cases these were discovered next to fords, mountain passes and in other strategic places, and close to contemporary settlements (Galán Domingo 1993; Díaz-Guardamino 2010: 373-89). Strabo's reference to the navigability of the Guadalquivir River beyond Córdoba in the Roman period (Chic García 1978: 8) suggests the strategic position of Montoro during the Late Bronze Age and Iron Age.

\section{Conclusion}

Despite the limitations of the epigraphic and contextual analysis, this study has offered preliminary conclusions concerning the Montoro stela. In essence, this stela seems to reflect the complex patterns of interaction that were established between literate and non-literate Iron Age communities of southern Iberia. In the Montoro stela, the Iberian tradition of (C) Antiquity Publications Ltd, 2017 
monumental stone stelae, dating back to the Neolithic, and powerfully materialised during the Bronze Age, was transformed to express a series of written signs that are, in some cases, unprecedented in the Iberian tradition. This perhaps suggests a 'foreign' origin for the signs, which were used in an 'unorthodox' and non-grammatically meaningful manner. Unlike other early Iberian epigraphic stelae (e.g. those with SW Palaeohispanic scripts) with almost exclusively incised signs, the Montoro stela was carved using a broader variety of techniques. Pecking was heavily used. This technique was commonly employed in the local rock art traditions (including 'warrior stelae') of southern Iberia during later prehistory. This exceptional convergence of cultural practices occurred in a location of strategic significance. Furthermore, the presence of Mycenaean pottery confirms this as the site of the oldest interactions between literate eastern Mediterranean and non-literate western European societies.

\section{Acknowledgements}

We wish to thank the following for their help in conducting this study: José María Calleja Serrano, who first unearthed the stone; José Romero Pérez (who, together with Jorge Illescas Luque, first noticed the engraved motifs); and José Ortiz García, director of the Montoro Municipal Museum.

\section{Supplementary material}

To view supplementary material for this article, please visit http://doi.org/ 10.15184 /aqy.2017.86

\section{References}

Chic García, G. 1978. Consideraciones sobre la navegabilidad del Guadalquivir en época romana. Gades 1: 7-19.

Correa Rodríguez, J.A. \& J.A. Zamora López. 2008. Un grafito tartesio hallado en el yacimiento del Castillo de Doña Blanca (Puerto de Sta. María, Cádiz). Palaeohispanica 8: 179-96.

De Hoz, J. 2010. Historia lingüistica de la Península Ibérica en la Antigüedad I. Preliminares y mundo meridional prerromano. Madrid: CSIC.

- 2011. Historia lingüística de la Península Ibérica en la Antigüedad II. El mundo ibérico prerromano y la indoeuropeización. Madrid: CSIC.

Díaz-Guardamino, M. 2010. Las estelas decoradas en la prehistoria de la Península Ibérica. Madrid: Universidad Complutense de Madrid.

Díaz-Guardamino, M. \& D. Wheatley. 2013. Rock art and digital technologies: the application of reflectance transformation imaging (RTI) and 3D laser scanning to the study of Late Bronze Age Iberian stelae. Menga: Journal of Andalusian Prehistory 4: 187-203.

Galán Domingo, E. 1993. Estelas, paisaje y territorio en el Bronce Final del suroeste de la Península Ibérica (Complutum Extra 3). Madrid: Universidad Complutense de Madrid.
García Sanjuán, L. \& M. Díaz-Guardamino. 2015. The outstanding biographies of prehistoric monuments in Iron Age, Roman, and medieval Spain, in M. Díaz-Guardamino, L. García Sanjuán \& D.W. Wheatley (ed.) The lives of prehistoric monuments in Iron Age, Roman, and medieval Europe: 183-204. Oxford: Oxford University Press.

Martín de la Cruz, J.C. 1988. Mykenische Keramik aus bronzezeitlichen Siedlungsschichten von Montoro am Guadalquivir. Madrider Mitteilungen 29: 77-93.

- 1990. Die erste mykenische Keramik von der Iberischen Halbinsel. Prähistorische Zeitschrift 65: 49-52.

Maspero, G. 1883. Nota en Corpus Inscriptionum Semiticarum I, fascículo 2: 215-16. Paris: Académie des Inscriptions et Belles-Lettres.

Mitchell, S. 2004. Gilgamesh: a new English version. New York: Atari.

O’Connor, M. 1996. Epigraphic semitic scripts, in P.T. Daniels \& W. Bright (ed.) The world's writing systems: 88-107. New York: Oxford University Press. 
Rogerio-Candelera, M.A., S. Soares de Figueiredo, P. Guimaráes \& A. Martinho BAPTISTA. 2010. Análisis de imagen de pinturas rupestres del yacimiento de Faia (Parque Arqueológico de Vila Nova de Foz Côa, Guarda, Portugal), in M.E. Sáiz Carrasco, R. López Romero, M.A. Cano Díaz-Tendero \& J.C. Calvo García (ed.) Actas del VIII Congreso Ibérico de Arqueometría: 419-27. Teruel: Seminario de Arqueología y Etnología Turolense.

Rogerio-Candelera, M.A., V. Jurado, L. Laiz \& C. SaIz-Jimenez. 2011. Laboratory and in situ assays of digital image analysis based protocols for biodeteriorated rock and mural paintings recording. Journal of Archaeological Science 38: 2571-78. https://doi.org/10.1016/j.jas.2011.04.020
Ruiz-Gálvez, M. 2009. ¿Qué hace un micénico como tú en un sitio como éste? Andalucía entre el colapso de los palacios y la presencia semita. Trabajos de Prehistoria 66: 93-118. https://doi.org/10.3989/tp.2009.09028

- 2013. Con el fenicio en los talones. Los inicios de la Edad del Hierro en la cuenca del Mediterráneo. Barcelona: Bellaterra.

SAss, B. 1988. The genesis of the alphabet and its development in the second millennium. Wiesbaden: Harrassowitz.

Stein, P. 2013. Lehrbuch der sabäischen Sprache 1. Teil: Grammatik. Wiesbaden: Harrassowitz.

ZAmora López, J.A. 2005. La práctica de escribir entre los primeros fenicios peninsulares y la introducción de la escritura entre los pueblos paleohispánicos. Palaeohispanica 5: 155-92.

Received: 27 May 2016; Accepted: 15 August 2016; Revised: 18 September 2016

(C) Antiquity Publications Ltd, 2017 